\title{
A Change in the Transportation Needs Today, a Better Future for Tomorrow - Climate Change Review
}

\author{
Leonard Ekpeni and Abdul-Ghani Olabi
}

\begin{abstract}
No sooner than later, the world will be living hell as a result of the transportation effects on our climate now escalating. The pressure is now growing towards their resultant effects to be totally eradicated in order to save our planet otherwise, the stabilisation of these effects; global warming, greenhouse gas (GHG) emission and degradation will need to be sought after. The world all over is at it now in an effort to restore our climate, to save it from the effects of these catastrophes/disasters.

On the proposition of the Kyoto Protocol in1997, the main focus was to decrease greenhouse emissions of mainly six gases - Carbon dioxide, methane, nitrous oxide, sulphur hexafluoride, Hydro fluorocarbons (HFCs) and Per fluorinated Compounds (PFCs). And transport alone, accounts for over $26 \%$ of global $\mathrm{CO}_{2}$ and has been regarded as one of the few industrial sectors wherein emissions are still on the increase, on this basis, researchers and policy makers are all at it to tackle the menace of climate changes through provision of sustainable transport. This paper focuses on the new and developed technologies like the renewable energy source [RES], which will be an alternative to transport fuels to avoid the dependence on petroleum which after effects are damaging to the world climate, and may probably not be there forever to continue serving the world ever increasing population. While the long term solutions are being sought, these alternatives will make do for now.
\end{abstract}

Keywords: Kyoto Protocol, global warming, sustainable transport, greenhouse gases, climate change. 


\section{Introduction}

Energy demand has been on the increase over the last decade due to the increasing demand of the world population particularly in the transport sector of the economy. As this demand increases, it has tends also to increase the impact of the damaging effect on our climate. To this effect, fossil fuels utilization has threatened the world economy in the areas of global climate change, world energy conflicts and energy source shortages [1]. The damaging effects of the fossil fuels to the world's climate through greenhouse gases (GHG), and has also now led to the researchers in finding an alternative solution to the limited supply of fossil fuels currently not meeting the much needed demand [2] and this is predicted to near exhaustion within the next 50 years [3]. Since transportation is needed by this oil, its reliance for the movement of goods and services is inevitable as production and manufacturing activities revolve around it [4]. This therefore means that the ever increasing of fossil fuels consumption will result in the petroleum production peak be imminent [5]. As transportation in the recent years has become an issue of great concerns due to the damaging effect from fossil fuel use, the management of the health effects of climate change will require inputs from all sectors of government and civil society as well as the collaboration between many academic disciplines and new ways of international cooperation that have until now eluded us. A new advocacy is needed as soon as possible if not already in place, so as to bring together governments, international agencies, non-governmental organisations (NGOs), communities, and academics from all disciplines in adapting to the resultant effects on transport through the new advocacy [6].

To this effect, the development of alternative energy sources has become of paramount importance to the world as a result, and has led researchers in finding alternatives for energy use. It is imperative that the climate be preserved by changes that are in place. Movement towards seeking more sustainable production methods, waste minimization, reduced air pollution, distributed energy generation, conservation of native forests, greenhouse gas emissions [7] and most importantly, to have control over these GHG emissions, led to an agreement being made with the overall pollution prevention targeted, hence the proposition Kyoto Protocol agreement [8].

In this chapter, focus is directed towards ways on reducing of the emissions of $\mathrm{Co}_{2}$ in the environment from the way we live and use transportation, as doing this will further help in saving the climate from global warming, depletion of the ozone layer and other vices that tends to interfere with the proper environmental living by humans and by so doing, our good health will be restored. 
Leonard Ekpeni and Abdul-Ghani Olabi

\section{Background: World Energy Conflicts}

The discrepancy between energy and teaming population in the world has aggravated in the conflicts currently being experienced worldwide. The love for huge wealth particularly that generated from fossil fuels is on the other hand pushing the world leaders of these oil nations to continuously stick on to power when especially democracy is not being exercised in this country.

For over 50 years now, the technological development in all sectors has improved and has changed the entire performance as well as the needs of the world including that of transportation. And these changes has been both positive and negative; for example, on the positive side, it has resulted in more stable and abundant food supply while on the negative side, it has continuously added to our environmental degradation, more dependence on fossil fuel as well as lowering our energy efficiency which in other words added to the climate effects we are experiencing now [9]. As this fossil fuel has become the main source of the world's energy, it has also being seen as a means of increasing the world's conflict [10]. Through our current energy need, and luxury goods and services especially those needing the use of energy generated from fossil fuel has increased well long ago and as such, has also added to the damaging effect of climate. Conflict over the control of valuable oil supplies has been persistent feature of international affairs since the beginning of the $20^{\text {th }}$ century and as oil become more scare and valuable; this has also increase the severity of its conflicts which has varies from one nation to another [11]. Since this product is extremely lucrative in terms of export particularly to the producing countries, they rely mainly on it as a major source of foreign revenue to them, Nigeria, Saudi Arabia and Iran for example, it accounts for 90-95, 90-95 and 80 per cent respectively as foreign revenue to them. Also, because whoever that controls the government of oil-producing states controls the allocation of oil revenues, these governments tends to stay in power in any way possible so as to still remain as benefactors to this product using means such as army rebellion, terrorism or coup d'etat [11].overcoming this dependence on fossil fuel, means that there should be alternatives means as a basis for solving the current climate menace otherwise, the competition for oil will remain a source of conflict so long as the demand for this fossil fuel rises faster than supply [11.] hence in consideration, renewable energy sources are now being looked at so as to preserve the climate and protect the environment. The negative effects of fossil fuel and other non-renewable energy sources has continue to be surfacing and in the transportation industry, our current need for it has also shown a rise in the menaces that are resultant from such usage, like the greenhouse gases, $\mathrm{Co}_{2}$ emission, global warming, depletion of the ozone layers as well as other variance that are detrimental to human health and environment. Though human activities are assumed to be responsible for almost all of the increase in greenhouse gases in the atmosphere since the last 150 years wherein the largest source of GHG emissions from human activities, for example; in the United States is from the burning of fossil fuels for electricity, heat and transportation [12.] but on a greater 
scale, this can be reduced to the barest minimum through changing our ways of living and shifting from the non-renewable to renewable energy sources.

\subsection{Energy source shortages}

Amidst the current energy crisis, it is of great concern to show that the energy supply source will not last for too long. The ever growing population whose demand need to be met and the shortage in the supply source are some reasons for this current situation. The environmental movement has been questioned of being the cause of the nation's energy crisis and that the balancing of environment and energy factors will be essential in determining policies to meet the demand of the crisis.

And as predicted by Dr. M. King Hubbert of Shell Oil in 1956, that US oil production would peak in 1970; this was disregarded by most oil experts and in furtherance to this, [13] asserts it that in 2005, oil production stopped growing, and the price of crude oil shot upward from $\$ 45$ per barrel to $\$ 140$ per barrel, we hit "peak oil" otherwise known as the "Hubbert's peak", a geological limitation to the supply of oil in the ground and with no additional supplies, a bidding war resulted in 2005 over the remaining oil in the ground. The eminent consequence of this is the high prices of oil which on other hand increases the prices of food as modern agriculture is an energy-intensive business [13]. The oil shortage will not only cause energy crisis in nations across the globe as it is being experienced now, but will also see the oil reserves being depleted and that again will make the price to rise sharply because of its nearing exhaustion and as such cannot meet the demand of the population.

Apart from the effects on our climate and health resulting from its use, the way of life need to be adjusted to suit the current energy need through alternative energy use of renewable energy sources (RES). This alternative has been considered necessary as the implications from these shortages need to be addressed regardless of whether it lasts another 40, 60 or 80 years as it is certain now that the resource is dwindling and that competition over it will become more intense. As it is acclaimed now that any factors that threatens fossil fuel stability, will result in the price rising and will in alternative, threatens investments as well [14].

In another development, in guiding against this shortage of energy source the best possible way is the minimization of the associated risk [15] and despite the best efforts to prevent a supply crisis; this cannot be totally prevented as one can still occur. In cases like this, energy security thinking dictates minimizing the impact of the crisis on national security and economic welfare. Also through strategic stockpiles, which are often owned and managed by the government, is one of the most effective ways to deal with a supply disruption crisis and/or price shock. Although this has not used yet as in the case of shortages but they are thought to 
be considered as essential in the minimization of price impact during a crisis situation.

\subsection{Renewable Energy Source Scenario}

As the world's climate is changing through the negative effects of greenhouse gas (GHG), global warming and bio degradation, so also efforts are required to have all these corrected through renewable energy sources [RES]. Not only now, in time to come this will play major role in the world's climate revival as it has been tagged; the power for a sustainable future.

This has been categorised into three parts; renewable resources, nuclear resources and fossil fuels [16]. Renewable energy studies is the most exciting aspect in that it is inherently positive as it offers the possibility of solutions to some of the society's most difficult problems $[16,17]$.

\section{Global Climate Change}

$21^{\text {st }}$ Century's Climate change $(\mathrm{CC})$ is now unequivocal [18] and has become a dominant issue that has arguably been thought of, and the earth's climate has changed over the year due to the warming and cooling of the cloud as depicted on [19]. [20] termed it a primary concerns for humanity in the $21^{\text {st }}$ century as it may affect health through different pathways, typical examples are as a result of vector-borne diseases, increased floods droughts and increased frequency and intensity of heat waves; to mention a few.

Maintaining the atmospheric new equilibrium means that there will be changes to its compositions which will ultimately now require balance in the achievement of the global climate change.

Since this has become a global problem, it therefore also requires a global response that embraces the interests and needs of all countries [21]. The world no longer sees it as an environmental problem alone, instead as an economic, trade and security issue which has increasingly dominate global and national policies as its impacts has become more severe.

It has also be considered as the potentially most important environmental problem that concerns energy; either greenhouse effect or global warming [21, 22].

Global warming is referred to as the measured increase in the average temperature of the earth, caused by the built up of some greenhouse gases in the atmosphere which has accumulated over time from the land use changes and fossil fuels combustion continually [23]. Fig. 1 below depicts the greenhouse gases under the 
Kyoto Protocol and their main generators as source. The first three have been estimated to account for $50 \%, 18 \%$ and $6 \%$ respectively of the global warming effect arising from human activities [18]. Just to note that greenhouse gases from the air transport has been exempted from the protocol.

\begin{tabular}{|l|l|}
\hline Greenhouse Gases & Main Sources \\
\hline Carbon Dioxide $\left(\mathrm{CO}_{2}\right)$ & $\begin{array}{l}\text { Fossil fuel combustion (e.g. Road transport, energy industries, other industries, residential, } \\
\text { commercial and public sector), forest clearing }\end{array}$ \\
\hline Methane (CH4) & Agriculture, landfill, gas leakage, coal mines \\
\hline Nitrous oxide $\left(\mathrm{N}_{2} \mathrm{O}\right)$ & Agriculture, industrial processes, road transport, other \\
\hline Perfluorocarbons $(\mathrm{PFCs})$ & Industry (e.g Aluminium production, semi-conductor industry) \\
\hline $\begin{array}{l}\text { HydroFluoroCarbons } \\
\text { (HFCs) }\end{array}$ & Refrigeration gases, industry (as perfluorocarbons) \\
\hline $\begin{array}{l}\text { Sulphur } \\
\text { (SF/6) }\end{array}$ & Elexaflical transmissions and distribution systems, circuit breakers, magnesium production \\
\hline
\end{tabular}

Fig. 1 Greenhouse basketed under the Kyoto Protocol and their main generators as modified from [18]

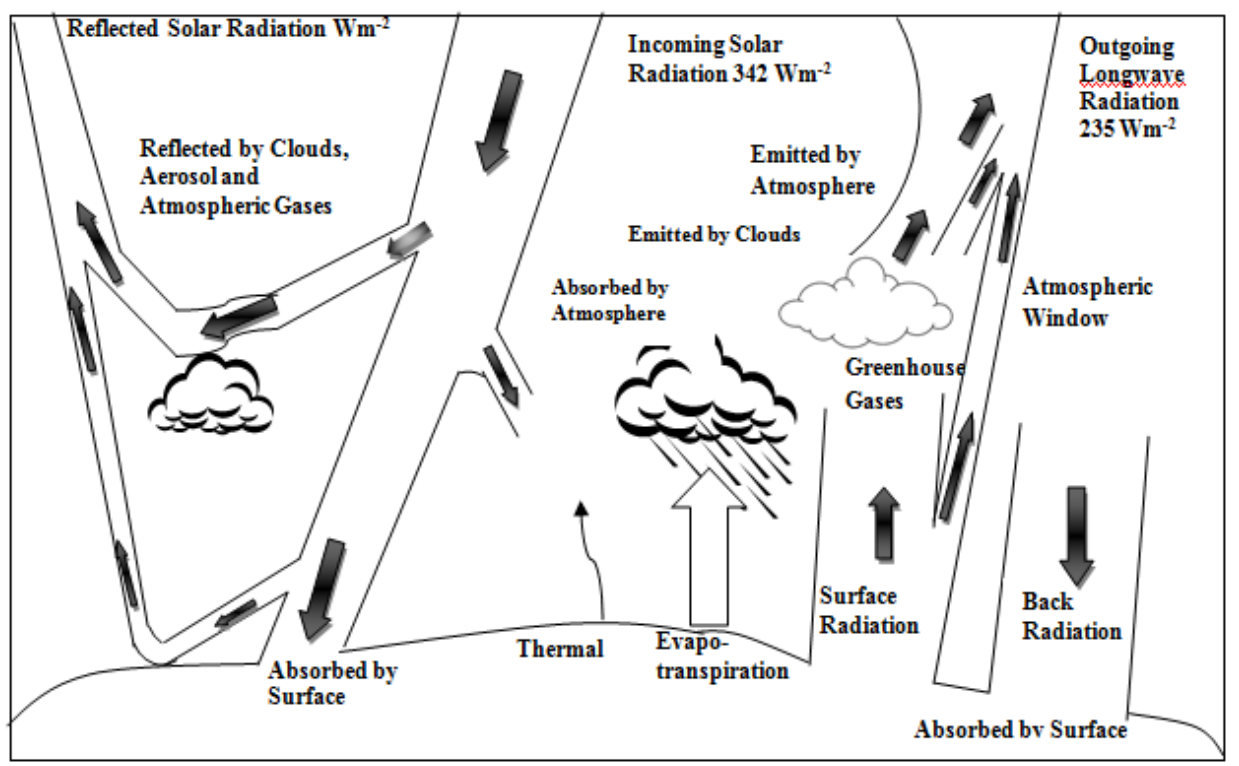

Fig. 2 Annual earth estimate and global mean energy balance; energy is transferred to the 
atmosphere via warming the air in contact with surface through long wave radiation that are absorbed by clouds and GHG as modified from [12]

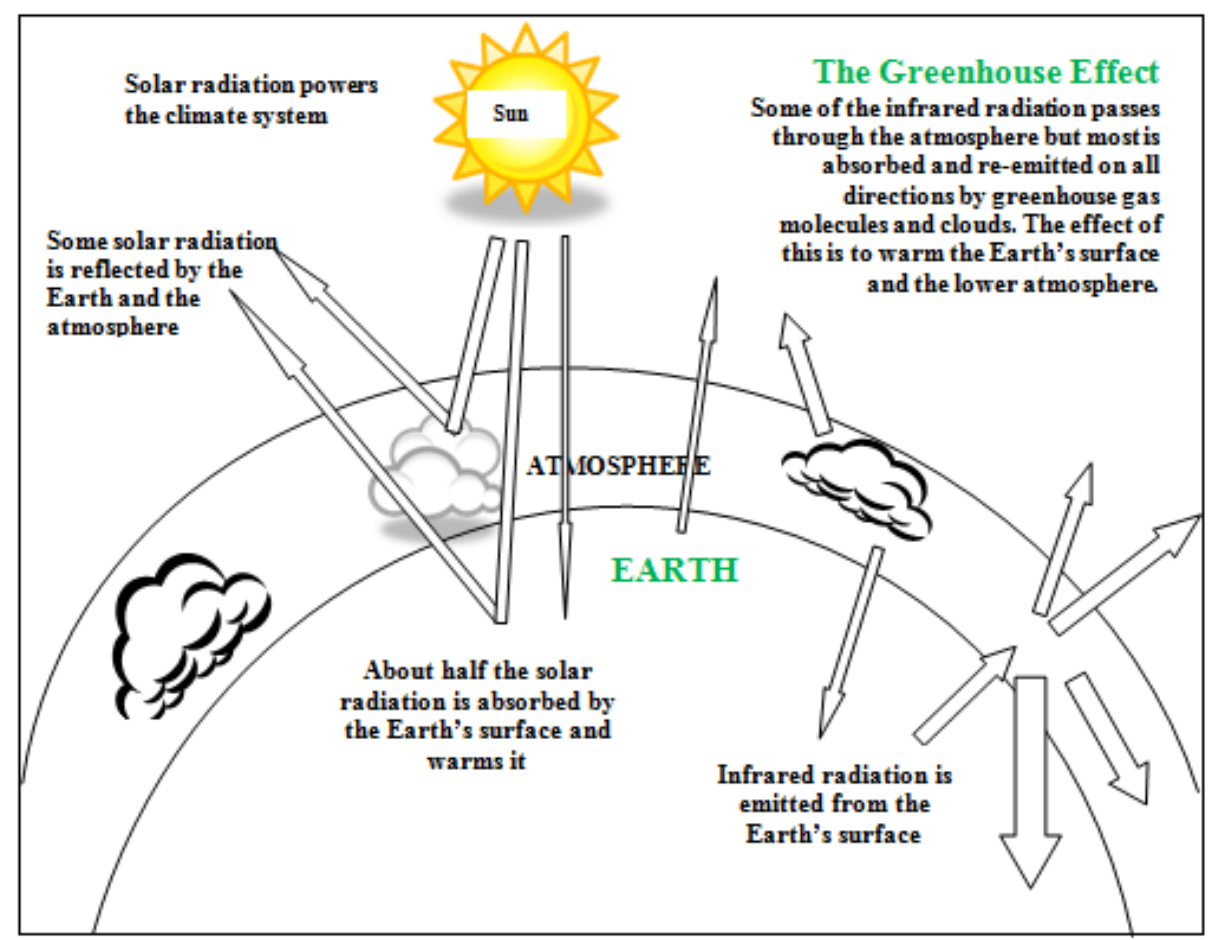

Fig. 3 Natural greenhouse effect with an idealized model as modified from [12].

\section{Transportation roles in the Society}

When the Kyoto protocol was proposed in 1997, transportation was considered as the key sector that needed to be tackled. This was to have GHG emissions down, the figure shows that percentage level of the 1990 level to 2008 level has been up by $47.5 \%$ for $\mathrm{CO}_{2}$ worldwide [21]. The reason behind this increment is as a result of oil being the dominant fuel source for transport movement and accounts for over $84 \%$ of the total energy use by the transport sector. For example in the UK alone, the transport industry has also seen a dramatic change with figures climbing 47\% from 28.1 Million tonne (Mtoe) in 1970 to 59.7 Mtoe in 2006 [24]. The 
population and the increase in Consumer Goods available have led to an increase in road haulage and personal transport needs.

This over dependent on oil makes transport a major GHG contributor and still one of the industries where emissions are still on the rise [25].

The impact of transport on the global climate is not limited to vehicle emissions as the production and distributions of fuel from oil, a 'wells to wheels' approach, produces significant amounts of GHG in it [26].

Fig. 5 below, indicates the energy use by end user wherein transport accounts for more as compared to others in the sectors; from 28,174 in 1970 to 59,780 in 2006 for UK data

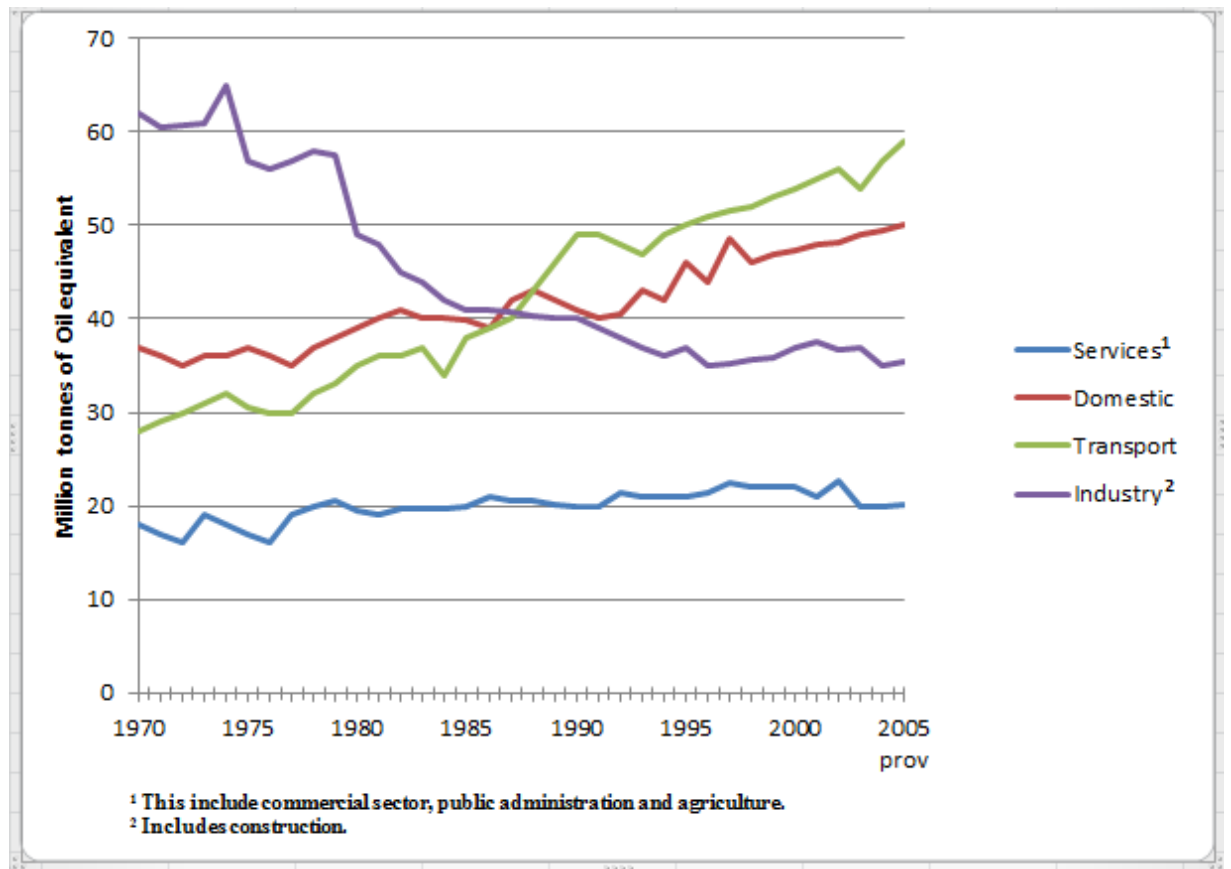

Fig. 4 UK Energy sectoral consumption as modified from [25]. 
Leonard Ekpeni and Abdul-Ghani Olabi

\begin{tabular}{|l|l|l|l|l|l|}
\hline \multicolumn{5}{|c|}{ Thousand tonnes of oil equivalent } \\
\hline & Industry & Transport & Domestic & Other final users & All final users \\
\hline 1970 & 62,333 & 28,174 & 36,884 & 18586 & 145,977 \\
1980 & 55,444 & 30,885 & 37,062 & 17,360 & 140,751 \\
1985 & 41,702 & 38,500 & 42,062 & 19,603 & 142,394 \\
1990 & 38,660 & 48,635 & 40,756 & 19,218 & 141,867 \\
1995 & 36,276 & 50,238 & 42,691 & 21,179 & 147,268 \\
2000 & 35,352 & 55,461 & 46,851 & 21,547 & 150,384 \\
2005 & 33,555 & 59,062 & 47,161 & 20,315 & 159,211 \\
2006 & 32,561 & 59,780 & 45,563 & 19,888 & 160,093 \\
\hline
\end{tabular}

Fig. 5 Final Energy Use by End User as modified from ([25]

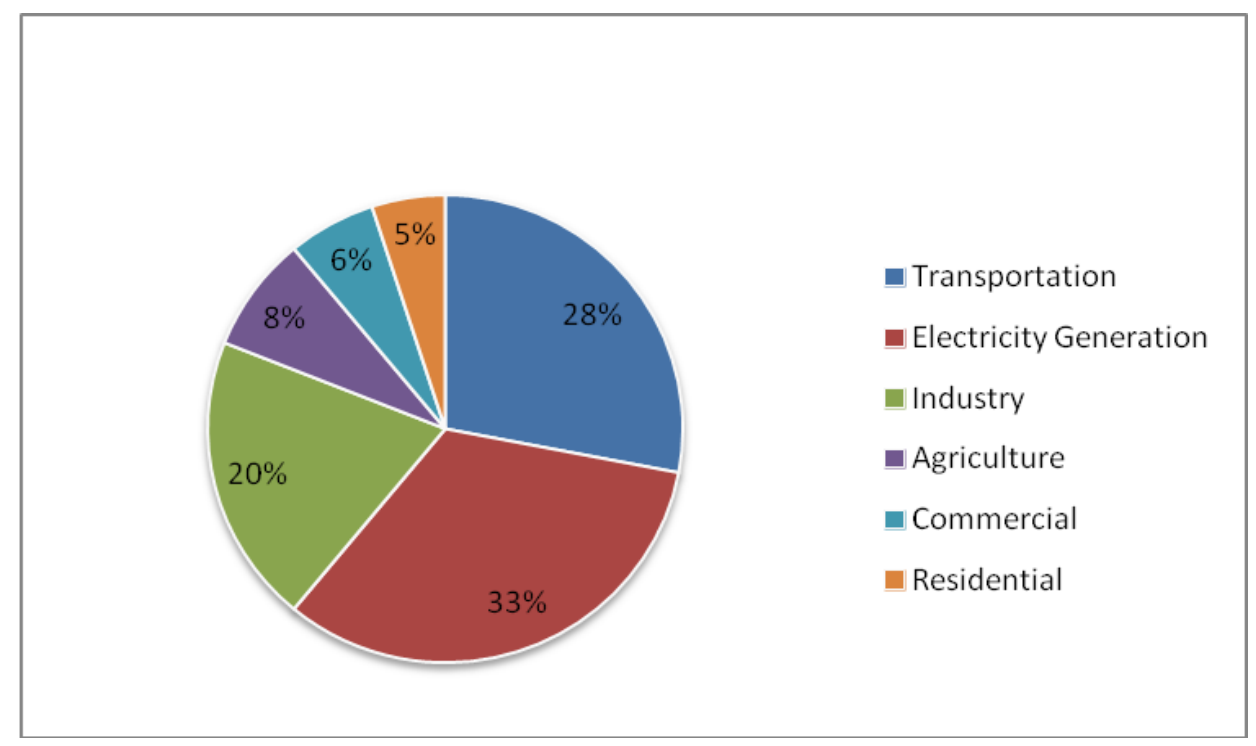

Fig. 6 Percentage of GHG emission in the US, 2006 (All gases in Teragram $\quad[\mathrm{Tg}] \mathrm{CO}_{2}$ ) as modified from [40] 
Also in the US from Fig. 6; the transportation sector accounts directly for $28 \%$ of the total GHG emissions in 2006, hence making that sector the $2^{\text {nd }}$ largest source of GHG emissions, while electricity generation taking the lead at 34\%. Almost $97 \%$ of transportation GHG emissions results as direct combustion of fossil fuels, as the remaining are due to $\mathrm{CO}_{2}$ from electricity (for rail) and Hydro Fluorocarbons (HFCs) emitted from vehicle air conditioners and refrigerated transport, as shown in Fig. 6 [40]

The End-Use emissions of $\mathrm{CO}_{2}$ depicted in Fig. $7 \mathrm{a}$ and $7 \mathrm{~b}$ indicates that the energy consumed in the transportation activities came from petroleum products; while more than $60 \%$ of the emissions resulted in gasoline consumption for personal vehicle use [40].

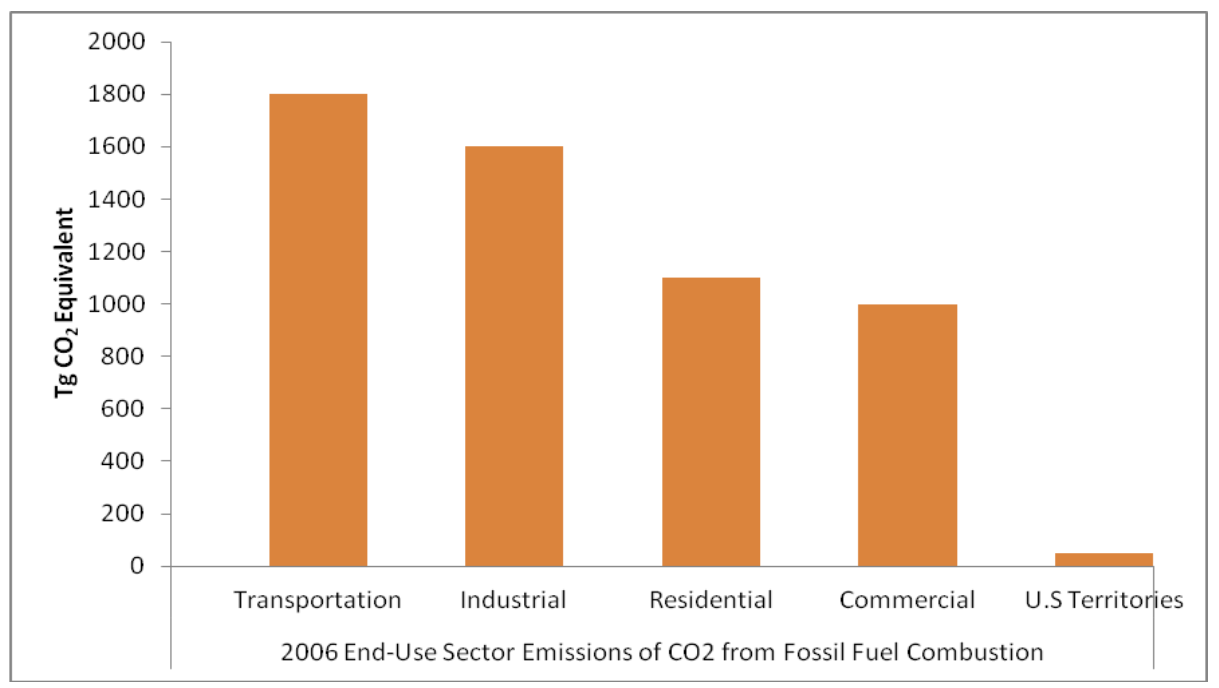

Fig. 7a: End-Use Sector Emissions of $\mathrm{CO}_{2}$ from Fossil Fuel Combustion as modified from [40] 


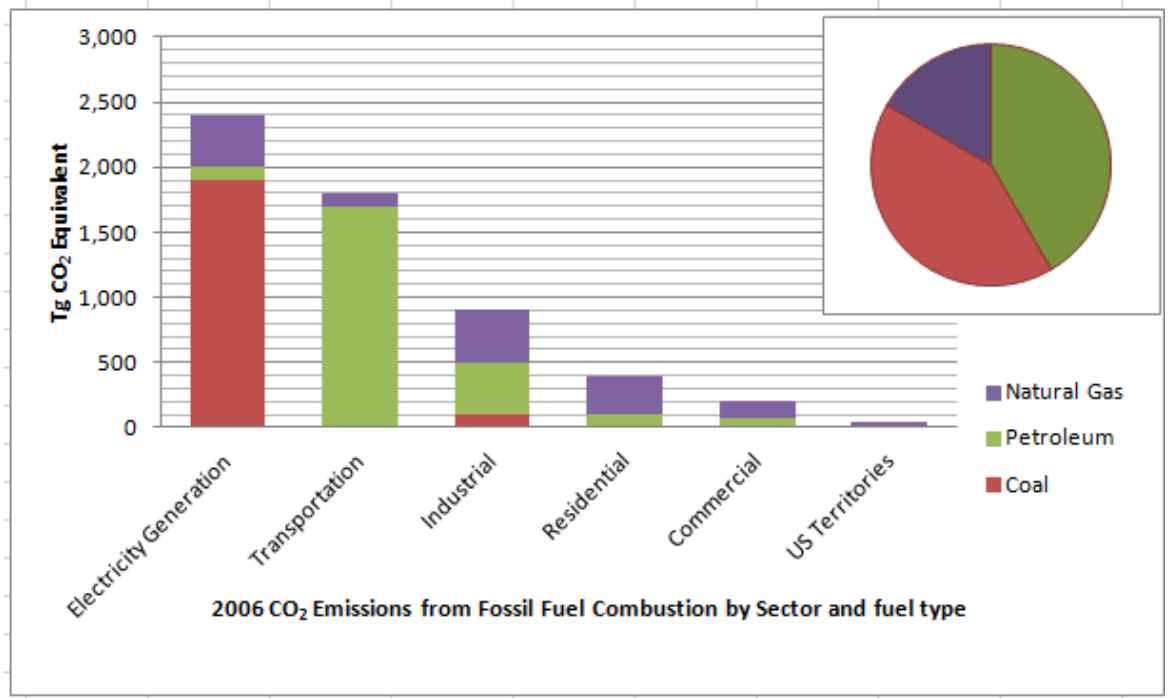

Fig. 7b: $\mathrm{CO}_{2}$ Emissions from Fossil Fuel Combustion by sector and fuel type as modified from [40]

The remaining are thought to be from heavy-duty vehicles and jet fuel in aircraft. It is estimated that transportation accounts for $28 \%$ emission of the GHG in the US and $26 \%$ worldwide.

Transportation sectors generally are experiencing expansion and there is also a general trend that considers the modes that are experiencing the most growth are the most polluting. Air transports shows the highest among all transport modes (Motor Car, Aviation, Road Freight, Rail, Ship, walking and cycling) [27]. Motor cars and aviation are favoured mode of transportation. This has resulted in the actual energy consumption and $\mathrm{CO}_{2}$ emissions from aviation significantly more damaging than the significantly more damaging than the others despite the fact that they are appearing lower when this is compared to that of motor cars but on the other hand, aviation is the biggest contributor to climate change. It is environmentally damaging than by the $\mathrm{CO}_{2}$ emission figures that are presumed, this is because other GHG are being released straight into the upper atmosphere, where the localised effects can be more damaging than the effects of just $\mathrm{CO}_{2}$ only [28].

\subsection{Transport Mitigations}

The world's value for material wealth, has led to the present infrastructure not being able to curtail with the large increases in the number of vehicles and as such, congestion is now becoming an ever increasing problem in so many towns and 
cities of the world. This has not only contributed to the air pollution and $\mathrm{CO}_{2}$ emissions but also with a great significant economic consequences [21]. To tackle this menace of reducing the damaging effect of $\mathrm{CO}_{2}$ emission from our road, there must be shift of car ownership to the use of public transports as this will reduce the numbers of vehicles on the road. For the effectiveness of this measure, there will need to be policies put in place like offsetting the affordability of car possession via indirect taxes implementations or having to increase parking charges at some destinations or fuel taxes levies [29].

Aviation on its own poses a greater problem when compared to other transportation means in that it emits into the gases like $\mathrm{CO}_{2}$ and nitrous oxide directly troposphere and stratosphere. Although the emission impact will vary as it is dependent on where the aircraft is flying but the NOx emission in the troposphere upper layer result in more ozone for radiative forcing than the same quantity released at the surface because some gases have an increased effect at altitude [30]

For the road freight, its growth has become an environmental and economic burden in terms of GHG emissions. About $45 \%$ of transportation energy is used in freight be cut down by half through technological advancement of the developed and well improved fuel efficiency [31]

Cycling and walking is the overall best to the environment in terms of saving our climate; this is zero carbon emission and envvironmentally friendly. This should be encouraged at all level not only for climate sake but also for the good health of every individuals and for this to be properly considered, every local authority, school and business even within family cycle, should consider 'soft' transport policy measures to encourage these [32] but for longer journey, other alternatives should be sought.

\section{New Generation/Developed Technologies}

\subsection{Fuel Cell}

Towards the technological advancement to save the climate, fuel cell has been developed. This uses hydrogen as its fuel for powering vehicle. And as a sustainable energy supply with little or no hydrocarbons use, it is preferred to fossil fuels because it is a clean and environmentally friendly fuel which produces water instead of GHG when combusted [1]. Though some methods of producing hydrogen generates GHG, but there are methods to capture and sequester the $\mathrm{CO}_{2}$ that is generated [33].

The most suitable source of hydrogen production is via water because it is clean, renewable and abundant [2]. Water dissociates into oxygen and hydrogen at high temperatures through this reaction below.

$\mathrm{H}_{2} \mathrm{O} \leftrightarrow \mathrm{H}_{2}+1 / 2 \mathrm{O}_{2}$ 


\subsection{Biofuel}

This is otherwise known as the sustainable fuel with no effect of $\mathrm{CO}_{2}$ to the environment. It works by recycling the natural occuring products such as the conventional crops; bioethanol from sugarcane, biodiesel from vegetable oils; this usually deliver a $10-90 \%$ reduction on a well-to-wheels or crop-to-car basis when compared to conventional fuels like gasoline and diesel [33]. Apart from the reduction of $\mathrm{CO}_{2}$ emission into the atmosphere, the use of non-intensively farmed crops or waste, enhance the GHG emission savings thereby increasing the overall availability of potential and production cost improvement.

\subsection{Battery Powered Electric Vehicle /Hybrid}

This is the zero emissions of $\mathrm{CO}_{2}$ at source and provide the advantages of electric propulsion with requiring fuel cell. That is; the energy management system being used in the optimization of the fuel economy of both engines since electric and combustion engines work better under different driving conditions.

\subsection{Carbon Tax and Audit (Carbon Footprint)}

This is a means towards reducing $\mathrm{CO}_{2}$ of every individual contribution to the environment also known as the foot print and its audit is the first step towards this development of carbon strategy. And as most nation have implemented these; particularly in the EU, Japan, USA and Canada, it reduces $\mathrm{CO}_{2}$ emissions in two ways; by increasing the prices of fossil fuels, this in a way will encourage more efficient use of energy through stimulating the development of zero-emission technologies and on the other hand, by changing the relative prices, it will encourage a proper shift in consumption from coal and oil to cleaner-burning natural gases which are environmental friendly. As compared to motor fuel taxes (MFT), carbon tax has a number of advantages;

- This is less regressive as compared to (MFT)

- It promotes global and local environmental quality while revenue are being raised.

- Shifting from the single-fuel energy taxes towards carbon tax implies that a required level of revenue can be raised at a lower tax rate [34]

And trading of emissions across all sectors of the economy addresses this by allowing emitters to purchase carbon offsets from businesses that are able to lower their own emissions below their allocation. On this basis, it will be of considerable idea in designing a climate policy that would tap all possible avenues to limit net 
$\mathrm{CO} 2$ emissions. For example, through offsetting emissions by storing carbon in soils, forests, and other forms of biomass in the United States, will have the potential in offsetting about 10 to $20 \%$ of U.S. emissions in the next $10-15$ years from now at relatively low cost [35].

\section{Conclusion}

The reduction of $\mathrm{CO}_{2}$ emissions will never cease to be of major concern for as long as fossil fuels are still the main form of energy usage across the globe. The way forward is the implementation of these new generation and developed technologies as explained above which will gradually take over fossil fuel and nuclear energy. It would be impossible to unite the entire world to tackle the issue of climate change/global warming because only a fraction of the entire world accepts the threat that it poses. In a gradual process, the shift of direction from fossil fuel and nuclear energy to alternative energy source [RES] will become acceptable by all and sundry. In the meantime, it will require people in authority to enforce any actions that are required for its implementation. As the world is in the midst and continuation of a period of drastic change four decades after the oil crises of the 1970s, everything from new information technologies to the rise of genetic engineering and the breakdown of traditional social structures are reshaping modern economies and lifestyles at an unprecedented pace [36] including the improvement of transportation and transportation systems over the period till date. Also in the implementation and further improvement of these ideas and plans, it should be borne in mind that certain changes in to be in proper place to improve the overall efficiencies and goals towards making this a huge success.

Some or parts of these changes are; technological change, which includes incremental technologies so as to make vehicles more technically efficient than they are today and at the same time lessen their fuel consumption/distance travelled, these will to a greater extent significantly reduce transport $\mathrm{CO}_{2}$ emissions over short to medium term though the term of transportation usage and improvement of transport need as to quality and $\mathrm{CO}_{2}$ emission has drastically reduced as compared to what it was 15-20 years ago. In essence, these technologies will further make transport systems and infrastructure more efficient, through reducing the need for vehicle travel to more efficient routing if the need be for it to be used as well as better in use fuel efficiency and mode switching; and new lower carbon fuels and fuels lower in GHGs on a 'well-to-wheels basis [37]. Development and improvement of hybrid Cars and designed of lower $\mathrm{CO}_{2}$ emissions aircraft has also be part towards this global issues of energy efficient and sustainable development. As zero-emission vehicles continue to exist, this will be history of alternative petroleum vehicles, which will continue to meet the needs of the people and as a result, reduce the over dependence on fossil fuel usage. 
These aircraft engines is expected to cut fuel consumption compared by $15 \%$, lower emissions of NOx and reduce the noise footprint by $75 \%$ [38].

Also to consider in terms of change is the behavioral change, this tends to contribute greatly to the reduction of $\mathrm{CO}_{2}$ emissions or saving energy through the framework of improving city living or its quality of life and as a result estimate the potential contribution of integrated pricing; this will be through pricing of road use decrees promulgated and enforced by the appropriate authorities; they will be charge with calculating the national road user charging scheme, and others to consider in the behavioral change will be soft factors and land use planning in reducing travel [39].

However, the potentials for carbon rationing should never be dismissed; as this is a system wherein tradable $\mathrm{CO}_{2}$ emission permits would have several effects on the overall well-being and climatic change of the environment through free yearly allocated $\mathrm{CO}_{2}$ budget given to individuals, and through the optimization of their travel patterns within the budget will assist in improving the emission of $\mathrm{CO}_{2}$ and GHGs released.

On the general view in this study, the overall success of the change in the transportation needs today so as to result in a better future for tomorrow, is the creation of awareness to all and sundry across the globe through proper communication channel and dissemination of information by way of education in different languages to the over 7 billion population across the globe while efforts are still being made and researches carried out to devise more meaningful ways in tackling this global menace.

\section{Acknowledgements}

The author wishes to acknowledge Dublin City University (DCU) for the use of its materials in this research as well as the supervisor to this research student ( $\mathrm{Dr}$ Abdul-Ghani Olabi) for the entire work carried out on this study.

\section{Nomenclature}

Chemical formula

$\mathrm{CO}_{2} \quad$ Carbon Dioxide

$\mathrm{CH}_{4} \quad$ Methane

PFCs Perfluorocarbon 


\title{
$\mathrm{N}_{2} \mathrm{O} \quad$ Nitrous oxide \\ HFCs Hydrofluorocarbons
}

SF/6 Sulphur hexafluoride

\author{
Acronyms \\ GHGs Greenhouse gases \\ RES Renewable energy Source \\ MFT Motor Fuel Taxes \\ PFCs Per fluorinated Compounds \\ NGO Non-Governmental Organizations \\ Mtoe Million tonne
}

\section{References}

[1.] Kothari R, Tyagi VV, Pathak A (2010) Waste-to-energy: A way from renewable energy sources to sustainable. Renewable and Sustainable Energy Reviews.14: 3164-3170

[2.] Park CY, Lee TH, Dorris SE, and Balachandran U (2010) Hydrogen production from fossil and renewable sources using an oxygen transport membrane. Hydrogen Energy 35: 4103 - 4110

[3.] Oman H (2003) Energy sources for the world's post petroleum era. IEEE Aerospace and Electronic Systems 18: 35-39

[4.] Isife CT (2010) Energy crisis and sustainable development in Nigeria. Sustainable Human Development Review 2 (2): 67 - 77.

[5.] Duncan RC, Youngquist W (1999) Encircling the peak of world oil production. Natural Resources Research. 8: 219-232.

[6.] Costello et al. (2009) Managing the health effects of climate change. Lancet and University College London Institute for global health commission. The lancet commissions, 373: 1693-733. [7.] Sim R.E.H. 2003. Bioenergy to mitigate for climate change and meet the needs of society, the economy and the environment. Mitigation and Adaptation Strategies for Global Change. 8:349-370

[8.] Nielsen JBH, Seadi TA, Popiel PO (2009) The future of anaerobic digestion and biogas utilization. Bioresource Technology. 100:5478-84.

[9.] Giampietro M, Pimentel D (1993) The tightening conflict: population, energy use, and the ecology of agriculture. http://www.npg.org/forum_series/tightening_conflict.htm > (Accessed December 12th, 2012) 
[10.] Barnett C (2006) Oil, conflict and the future of global energy supplies. http://www.globalresearch.ca/oil-conflict-and-the-future-of-global-energy-supplies/1781 (Accessed December 12th 2012)

[11.] Klare MT (2004) Blood and oil: The dangers and consequences of America's growing petroleum dependency. http://www.hampshire.edu/academics/22172.htm $>$ (Accessed December 12th, 2012)

[12.] IPCC (2007) Summary for policymakers. In: Climate Change 2007: The Physical Science Basis. Contribution of Working Group I to the Fourth Assessment Report of the Intergovernmental Panel on Climate Change [Solomon, S., Qin, D., Manning, M., Chen, Z., Marquis, M., Averyt, K.B., Tignor, M. and Miller, H.L. (eds.)]. Cambridge University Press, Cambridge, United Kingdom and New York, NY, USA http://www.epa.gov/climatechange/ghgemissions/sources.html (Accessed on December 10th, 2012)

[13.] Deffeyes KS (2001) Hubbert's Peak: The impending world oil shortage. Princeton University Press, NJ, USA

[14.] Perovic J, Mockli D (2006) Energy security: oil shortages and their implications. CSS Analyses in security policy. 1: 2. CSS An ETH Center. http://www.css.ethz.ch/publications/pdfs/CSS-Analyses-2.pdf > (Accessed December 12th, 2012)

[15.] Hippel, DV, Suzuki T, Williams JH, Savage T, Hayes P (2011) Energy security and sustainability in Northeast Asia. Energy Policy 39 6719-6730

[16.] Demirbas A (2000) Recent advances in biomass conversion technologies. Energy Educational Science and Technology 6: 19-40

[17.] Boyle G (1996) Renewable Energy: Power for a Sustainable Future. Oxford University Press, Oxford, UK.

[18.] UNFFCCC (2003) (Accessed on March $8^{\text {th }}$, 2012)

[19.] IPPC (2007) www.int/resource/docs/publications/unitingonclimate_eng.pdf (Accessed on March 11, 2012)

[20.] Tingem M, Rivington M (2009) Adaptation for crop agriculture to climate change in Cameroun: turning on the heat. Mitigation and Adaptation Strategies for Global change. 14:153 68

[21.] Chapman L ( 2007) Transport and climate change: A review. Transport geography. 15:35467

[22.] Panwar, NL, Kaushik, SC, Kothari S (2011) Role of renewable energy sources in environmental protection: A review. Renewable and Sustainable Energy Review.15: 1513-24

[23.] Weubles DJ , Jain AK (2001) Concerns about climate change and the role of fossil fuel use. Fuel Processing Technology. 71:99-119

[24.] Defra (2007) www.defra.gov.uk/environment/climatechange/uk (Accessed on March 22, 2012) 
[25.] WBCSD (2001) World Business Council for Sustainable Development. Mobility 2001: World Mobility at the end of the twentieth century and its sustainability. [www. wbcsdmobility.org (Accessed on April $\left.\left.1^{\text {st }}, 2012\right)\right]$

[26.] Weiss MA, Heywood JB, Drake EM, Schafer A, AuYeung FF (2000) On the Road in 2020 - A life Cycle Analysis of New Automobile Technologies, Energy Laboratory, MIT, October 2000.

[27.] Lenzen M, Dey C, Hamilton C (2003) Climate Change. In: Henser DA, Button KJ (Eds), Handbooks in Transport 4: Handbook of Transport and the Environment. Elsevier: pp. 37-60

[28.] Cairns S, Newson C ( 2006) Predict and decide. Aviation, Climate Change and UK Policy, Environmental Change Institute, pp.122

[29.] IEA (International Energy Agency). (2000) Transportation Energy. www.iea.org (Accessed on April 18, 2012)

[30.] Penner JE, Lister DH, Griggs DJ, Dokken DJ, McFarland F (1999) IPCC Special Report: Aviation and the Global Atmosphere. Cambridge University Press, UK pp.373.

[31.] IMO (International Maritime Organisation). (2000) Prevention of Air Pollution from Ships, Consideration of an IMO Strategy for Greenhouse Gases Reduction: MEPC 45/8/3, NY.

[32.] Cairns S, Sloman L, Newson C, Anable J, Kirkbride A, Goodwin, P (2004) Smarter Choices: Changing the way we travel, Department of Transport.

[33.] www.Biofuels_Fact_Sheeton renewable energy.pdf (Accessed on April 14th, 2012)

[34.] Muller F, Hoerner JA (1994) Greening State Energy Taxes: Carbon Taxes for Revenue and the Environment. Pace Environmental Law Review. 12 Pace Envtl. L. Rev. 5. (www.digitalcommons.pace.edu/pelr/vol12/iss1/2)

[35.] Chameides .W , Oppenheimers M (2007) Climate change: Carbon trading over taxes. Policy Forum. Science Vol. 315. www.sciencemag.org

[36.] Lenssen N, Flavin, C (1996) Sustainable energy for tomorrow's world: The case for an optimistic view of the future. Energy Policy. 24: (9) 769-781

[37.] IEA (International Energy Agency). (2004) Transportation Energy. www.iea.org (Accessed on June 10, 2012)

[38.] http://www.aviationbenefitsbeyondborders.org/environmental-efficiency/case-studies/newengines-offer-ever-lower-fuel-burn-and-emissions (accessed June11th, 2012)

[39.] Hickman R, Banister, D (2005) Towards a 60\% reduction in UK transport carbon dioxide emissions: a scenario building and backcasting approach. Sustainable transport and land use. ECEEE 2005 summer study - what works \& who delivers?

[40] www.epa.gov/climatechange/emissions/downloads/08 CR.pdf (Accessed on April 7, 2012) 